\title{
Mário de Andrade fotógrafo-viajante e a linguagem modernista
}

\author{
Douglas Canjani ${ }^{1}$
}

Resumo

Mário de Andrade foi, além do escritor abrangente e vívido que conhecemos, um pioneiro da fotografia modernista brasileira. Essa faceta de sua produção estética, embora menos conhecida, reveste-se de grande importância conforme avançam, entre nós, os estudos sobre o desenvolvimento de uma visualidade fotográfica eminentemente modernista. A experiência fotográfica de Mário, tão densa e original quanto episódica (resume-se basicamente à década de 1920, adensando-se nos anos de 1927 - 1929, época de suas viagens ao Norte e Nordeste do Brasil), sofreu forte influência das principais vertentes da produção modernista europeia, que ele acompanhava principalmente por meio de revistas europeias de arte, como L'esprit nouveau e Der Querschnitt, as quais assinava. Analisamos aqui alguns expedientes de linguagem que caracterizam suas fotos, abrigadas no acervo do IEB-USP.

\section{Palavras-chave}

Fotografia, viagem, modernismo.

Recebido em 29 de abril de 2013

Aprovado em 30 de julho de 2013

CANJANI, Douglas. Mário de Andrade fotógrafo-viajante e a linguagem modernista. Revista do Instituto de Estudos Brasileiros, Brasil, n. 57, p. 51-82, 2013.

DOI: http://dx.doi.org/10.11606/issn.2316-901X.v0i57p 51-82

1 Pontifícia Universidade Católica (PUC, São Paulo, SP, Brasil). 


\title{
The Travel Photographs of the Brazilian Writer Mário de Andrade and their Connection to the Modernist Visual Language
}

\author{
Douglas Canjani
}

\begin{abstract}
Mário de Andrade, one of the most important modernist Brazilian writers, developed an intense but short interest in photographing in the 1920's. His pictures taken while in travels in the north and northeast of Brazil (1927 - 1929) are outstanding examples of a modernist way of creating pictures, which are both documentary and experimental. He, who never left Brazil, was influenced by European vanguards, which he knew by art magazine reproductions. We analyze here some of these travels' pictures, which are housed at the archives of IEB-USP.
\end{abstract}

Keywords

Photography, travels, modernism. 


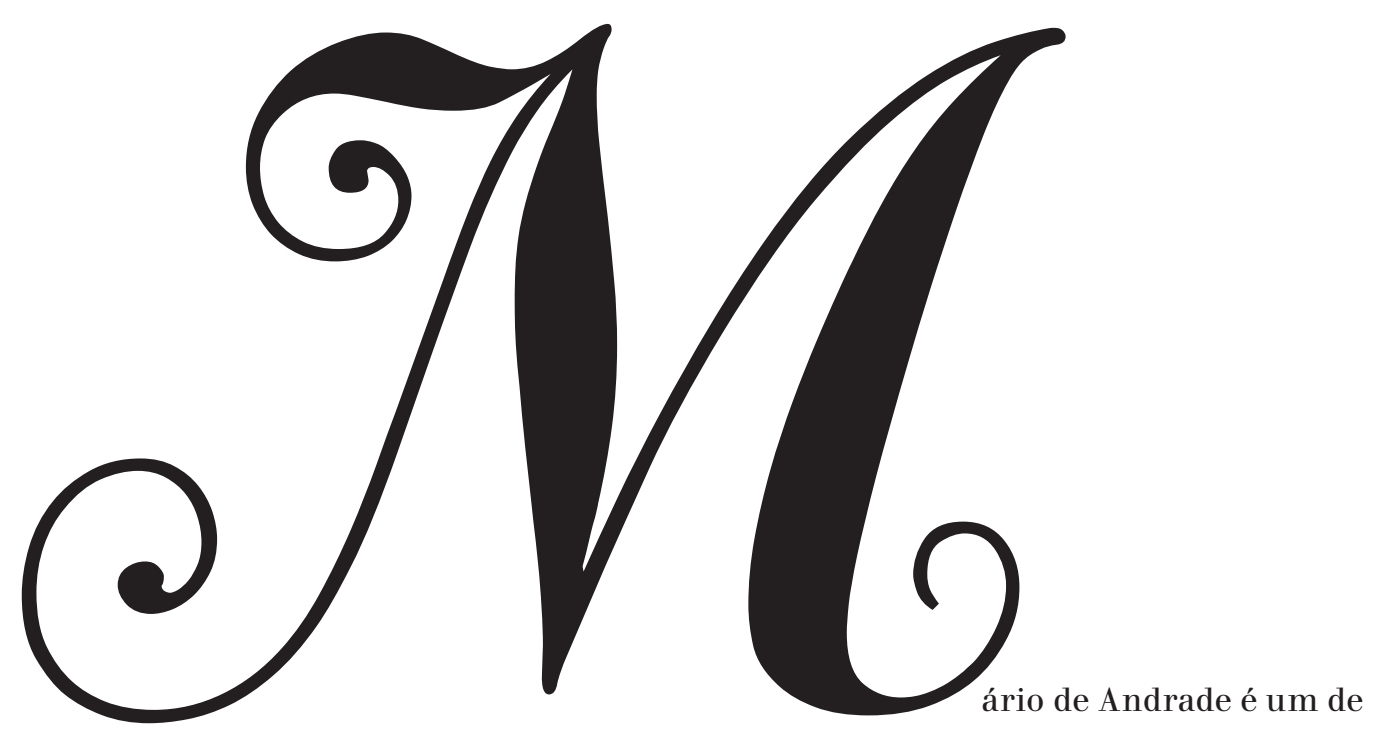

nossos intelectuais mais fecundos e abrangentes. Ele foi poeta, romancista, cronista, jornalista; pesquisador e professor de música, historiador da arquitetura, crítico literário e de artes plásticas. Estabeleceu um diálogo estimulante entre as culturas popular e erudita, numa época em que a separação entre elas era estrita. Promoveu, assim como os outros modernistas de sua geração, uma revisão dos valores culturais vigentes no início do século XX, buscando formas genuinamente brasileiras de expressão, tanto na literatura quanto nas artes visuais e na música. Apesar desse viés nacionalista, buscou o que havia de mais moderno e cosmopolita em termos estéticos, incorporando novas formas expressivas e alargando os debates críticos da época.

Mas uma faceta menos conhecida de sua produção e de seus vastos interesses é seu envolvimento com a fotografia. Mário não apenas produziu fotografias de alto teor artístico e documental, extrapolando os cânones então vigentes na produção fotográfica nacional, como dedicou mais tarde pequenos artigos à produção alheia ${ }^{2}$.

Tendo comprado em 1923 uma máquina fotográfica Kodak (que ele grafava "Codaque", assim como inventou o neologismo "fotar" para designar o ato de fotografar), ele passou a exercer a linguagem fotográfica na vida privada e nos interesses profissionais, deixando um rico acervo pessoal de fotografias. Mas foi nas suas duas viagens que ele denominou “etnográficas", ao Norte (1927) e Nordeste (1928 - 1929) do Brasil, que Mário explorou em profundidade as possibilidades que a linguagem

2 ANDRADE, Mário de. Fantasias de um poeta (fotomontagens de Jorge de Lima) [1939]. In: Será o Benedito! São Paulo: Educ, 1996. págs. 71-76. O homem que se achou (fotos de Jorge de Castro) [1940]. In: Será o Benedito! São Paulo: Educ, 1996. págs. $77-81$. 
fotográfica podia então oferecer. As cerca de quinhentas fotos tiradas nas duas viagens nos mostram um rico conjunto a ser estudado. Apresentamos aqui alguns exemplos dessa produção, buscando evidenciar, na análise de suas fotos, questões de linguagem fotográfica e o modo como elas foram construídas ou como podem ser associadas a determinados cânones visuais.

Em 1927, cinco anos depois da Semana de Arte Moderna e já tendo feito com o grupo modernista viagens a Minas (1924: viagem de "redescoberta do Brasil"), Mário parte para uma viagem de três meses pela Amazônia (13 de maio a 15 de agosto). Saindo do Rio de Janeiro, de navio rumo a Manaus, ele para em algumas capitais litorâneas, alcançando a Amazônia e, como ele mesmo diz, "até o Peru pelo [rio] Madeira até Bolívia e por Marajó até dizer chega". Ao longo do extenso trajeto, Mário fez as anotações em forma de diário de viagem que geraram o livro inacabado $O$ turista aprendiz (editado apenas em 1976), e produziu um rico acervo de fotografias que enfoca as populações e paisagens ribeirinhas e apresenta ousadas investigações formais.

As anotações da viagem ao nordeste, feita entre novembro de 1928 e fevereiro de 1929 por Pernambuco, Paraíba e Rio Grande do Norte foram editadas como crônicas de jornal ao longo do ano de 1929. As fotografias então tiradas registram seus encontros com amigos como Luís da Câmara Cascudo, com artistas populares, bem como aspectos da vida cotidiana e das cidades, vistos sob um prisma modernista, em que a documentação não exclui a forma inovadora.

Surpreendentemente, a incorporação da produção fotográfica de Mário à história da fotografia brasileira é recente. Parece que, pelo fato de Mário ser escritor, suas fotos passaram desapercebidas aos (então poucos) estudiosos da fotografia. Apesar de as fotos de viagem terem sido dadas a conhecer (algumas em 1976, na edição do texto d'O turista aprendiz, outras tantas em Mário de Andrade: fotógrafo e turista aprendiz, 1993, por Telê Ancona Lopez, vide nota 2), foi apenas muito recentemente que Mário começou a ser citado na historiografia fotográfica brasileira.

No texto "Arquitetura e fotografia no século XIX" são citadas como exemplo de esforço de documentação isenta; não se mencionam as características subjetivas do olhar que as preside. Por volta de 2002, em duas situações, Rubens Fernandes Júnior ${ }^{4}$ incorpora Mário à

3 CARVALHO, Maria Cristina Wolff de; WOLFF, Sílvia Ferreira Santos. Arquitetura e fotografia no século XIX. In: FABBRIS, Annateresa (org.). Fotografia: usos e funções no século XIX. São Paulo: Edusp, 1991.

4 FERNANDES JÚNIOR, Rubens. A fotografia expandida. 2002. 275 f. Tese (Doutorado em Comunicação e Semiótica) - Pontifícia Universitária Católica de São Paulo, 2002. 
linhagem de artistas-fotógrafos, dedicados à experimentação fotográfica: em sua tese de doutorado e na seção devotada à fotografia da exposição levada à Valência, Brasil 1920-1950: da antropofagia a Brasília, em curadoria geral de Jorge Schwartz. Trabalhos importantes como Afotografia moderna no Brasil ${ }^{5}$ e como a seção "Fotografia" da História geral da arte no Brasil ${ }^{6}$ não o mencionam, o primeiro por cingir-se ao fotoclubismo, o segundo por deter-se sobre os aspectos documentais da fotografia.

Se a produção fotográfica de Mário não é a de um "profissional" que se dedica contínua e primordialmente à linguagem visual, ela se faz, talvez justamente por seu caráter episódico, numa intensa turbulência, transitando entre uma experimentação ousada e um documentarismo direto, entre o instantâneo e olhar contemplativo: apesar de "amador", seu olhar (assim como sua relação técnica com a câmera) exibe maestria e vigor na apreensão de geometrias ínsitas ao campo visual, na exploração de luzes e contraluzes, na apropriação simbólica de elementos visuais de caráter narrativo. Sua inteligência figural distingue-se de grande parte da amostragem fotográfica brasileira de sua época, como veremos a seguir.

Perguntamo-nos: como haverá seu olhar se formado, especificamente no que concerne ao repertório fotográfico? Se analisarmos a produção fotográfica da época, veremos que as ousadias de Mário (e mesmo suas fotos mais comportadas) movem-se num campo destacadamente experimental e avançado, tributário das conquistas do modernismo mais "heroico". As fotos de Mário se colocam em sintonia com as tentativas mais avançadas de seu tempo. A título de comparação, convém considerar que 1923, momento em que Mário compra sua Kodak, é o ano da morte de Marc Ferrez, cuja obra fotográfica, vasta e importante, é emblemática do tipo de atuação então corrente: de cunho eminentemente documental, traz, na construção da imagem, a marca das convenções figurativas do século XIX e dos limites técnicos de seu equipamento (grande formato, negativo de vidro, tripé).

5 COSTA, Helouise; SILVA, Renato. Afotografia moderna no Brasil. São Paulo: Cosac Naify, 2004.

6 KOSSOY, Boris. Fotografia. In: ZANINI, Walter (org.). História geral da arte no Brasil. São Paulo: Instituto Moreira Salles, 1983, 2 v. 


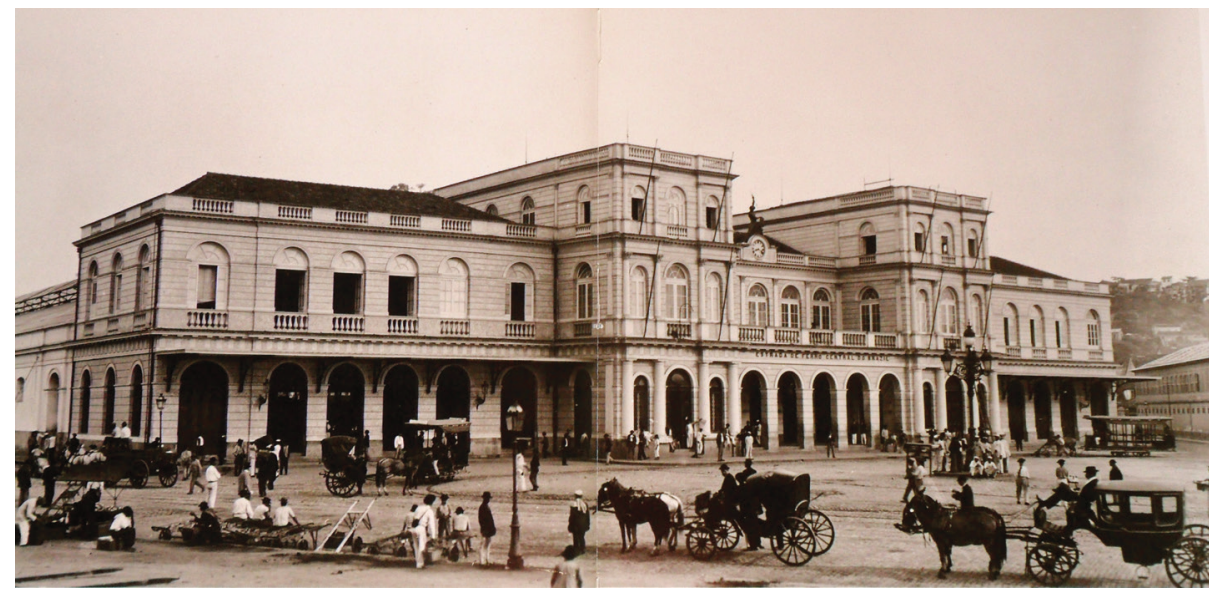

Figura 1: Marc Ferrez, Estação Central do Brasil, Rio de Janeiro, 1899.

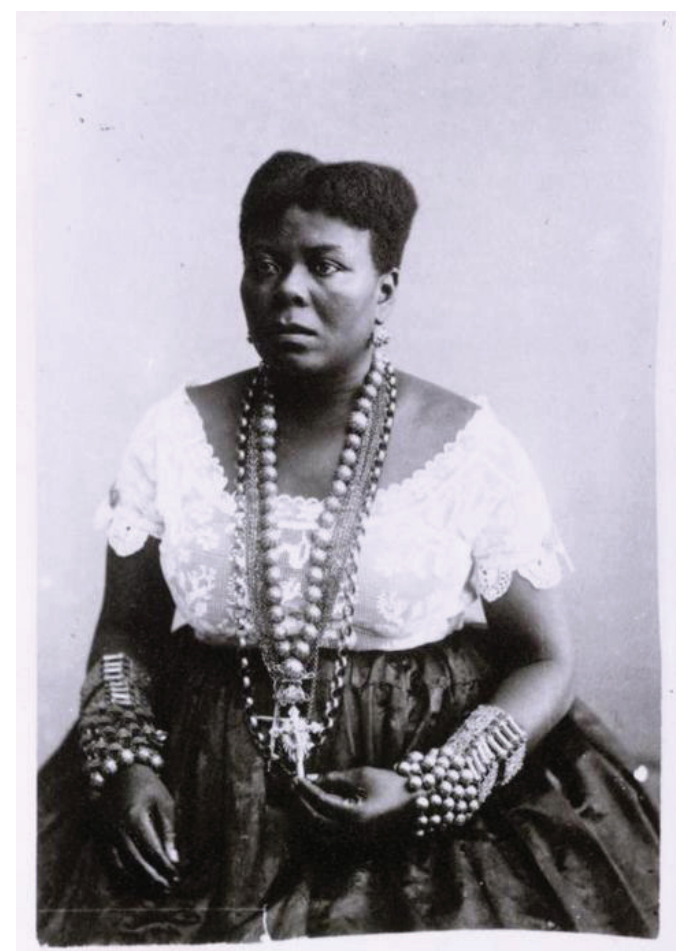

Figura 2: Marc Ferrez, Baiana, s/d. 
Sem dúvida tivemos, na fotografia brasileira do início do século, exemplos de iniciativas de caráter experimental e inovador, exemplificado pela célebre fotomontagem Os trinta Valérios, de Valério Vieira. No entanto, essa imagem, ganhadora da medalha de prata na exposição de Saint Louis (EUA) em 1904, de grande virtuosismo técnico e certo apelo anedótico (o fotógrafo apresenta-se em trinta poses diferentes em um espaço de estúdio), passa ao largo das questões que logo em seguida seriam impostas pela agenda modernista, sem maiores arroubos compositivos (isto é, abstratos) nem narrativos (marcados, poucos anos depois, pelas poéticas expressivas das vanguardas).

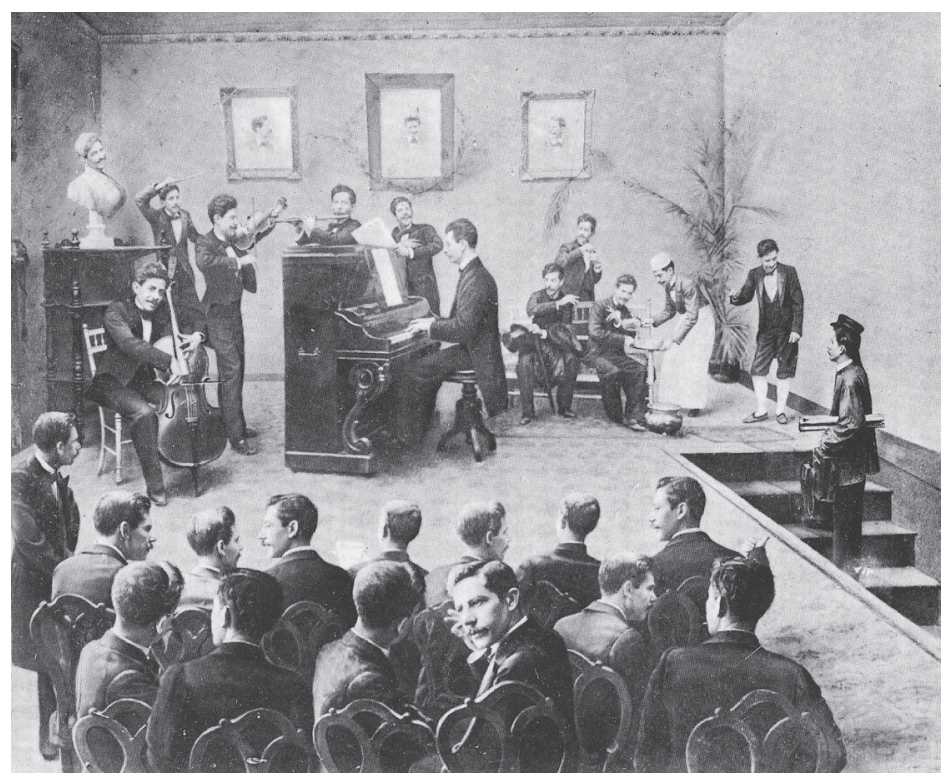

Figura 3: Valério Vieira, Os trinta Valérios, 1902.

Consideremos ainda que a década de 1920 assistiria ao surgimento, no Brasil, da imprensa ilustrada por fotografias (a revista O Cruzeiro foi lançada em novembro de 1928, para tornar-se o veículo impresso de maior circulação nacional), sintoma do surgimento de novas práticas sociais relativas aos usos da imagem gráfica; mesmo assim, eram fotos com um forte viés pictorialista, submetidas a regras clássicas de composição e à temática assimilável ao gosto do público consumidor destas revistas. Apenas na década de 1940 a imprensa ilustrada se aproximaria do que 
poderíamos chamar de "fotojornalismo moderno", ligado ao instantâneo e ao que Cartier-Bresson chamaria de "instante decisivo".

Por outro lado, se compararmos a obra de Mário com as experiências de fotógrafos americanos que atuavam na época (como na importante Farm Security Administration, instituída em 1935, e que contava com Walker Evans, Dorothea Lange, Ben Shahn, entre outros), veremos que a linguagem visual de Mário inclinava-se mais ao modelo europeu e experimental. Na viagem de Walker Evans a Havana em 1933, por exemplo, a serviço de um diário americano (portanto na condição de viajante e de fotojornalista profissional), Evans fez retratos bastante sóbrios e compatíveis com o uso em jornal isto é, realmente documentais. Apesar de possuir recursos expressivos e técnicos que lhe possibilitavam a produção de "instantâneos", como os feitos em Nova Iorque, uma grande parte de sua produção reveste-se de um tempo lento, como se cada foto fosse previamente meditada e mesmo feita com tripé. Mário, em viagem, tomou liberdades de linguagem fotográfica que Evans só tomou "em casa". De um modo geral, Mário incorreu em ousadias (o posicionamento diagonal da câmera, o apreço pela apreensão do instante), que não faziam parte do vocabulário dominante de Evans (que prefere, geralmente, a frontalidade e uma temporalidade muito mais lenta).

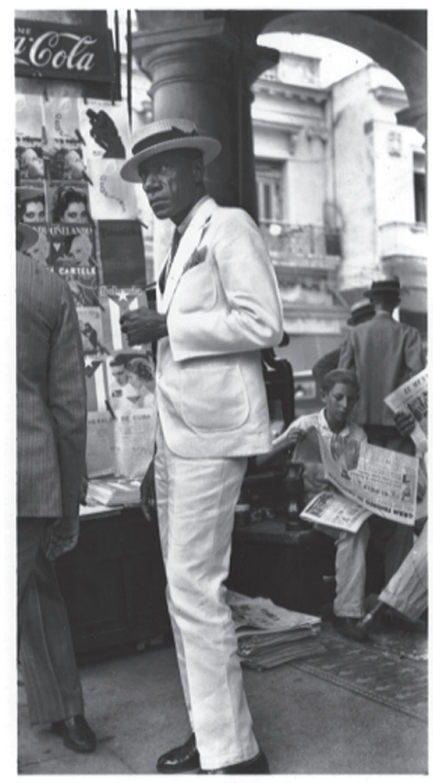

Figura 4: Walker Evans, Citizen in Downtown Havana, 1933.

7 COSTA, Helouise. Pictorialismo e imprensa: o caso da revista O Cruzeiro (19281932). In: FABBRIS, Annateresa (org.), op. cit., 1991. 


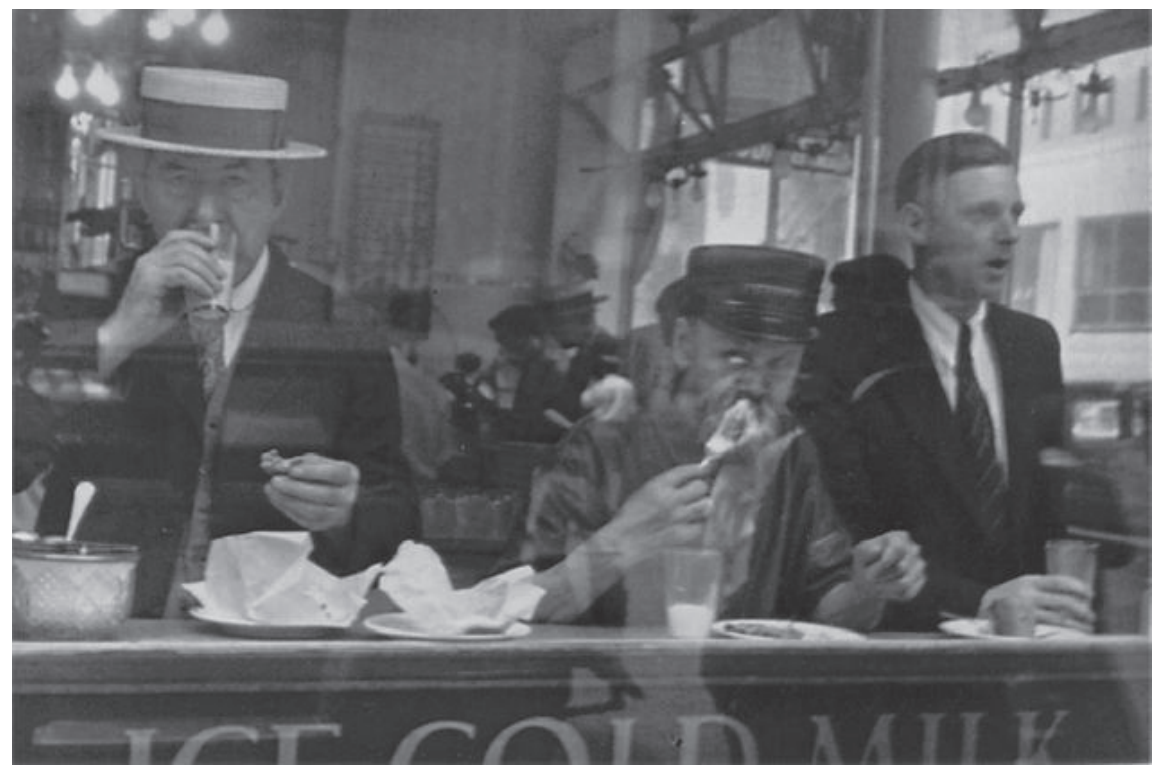

Figura 5: Walker Evans, City Lunch Counter, Nova Iorque, 1929.

O fato é que, a despeito de obras como a de Valério Vieira (vale lembrar, um experimento de estúdio), a fotografia não fez parte das preocupações de primeiro momento de nossos modernistas, a tal ponto que o crítico Paulo Herkenhoff ${ }^{8}$ nos conta que em 1921, num artigo sobre Brecheret, Oswald de Andrade escrevia que

[...] de fato, o artista é o ser do privilégio que produz um mundo supra-terreno, antifotográfico, irreal que seja, mas um mundo existente, chocante, profundo. Mas isso que faz o critério julgador das nossas populações (frases assim: como está parecido! Que beleza! É como se fosse...) é a maior vergonheira de uma cultura. Arte não é fotografia! Nunca foi fotografia! Arte é expressão, é símbolo comovido.

Evidentemente, Oswald prega a autonomia das artes visuais frente ao que se poderia chamar de resquício naturalista ou realista (um apreço pela dimensão aparente) do século XIX, mas tal assertiva parece

8 HERKENHOFF, Paulo. Fotografia: o automático e o longo processo de modernidade. In: TOLIPAN et al. Sete ensaios sobre o modernismo. Rio de Janeiro: Funarte, 1983 . 
colocar as possibilidades expressivas da fotografia em posição redutora, de mera reprodução da realidade.

Dentro deste panorama, a produção fotográfica de Mário surpreende. Apesar de ter uma atuação destacada nos principais debates estéticos do modernismo brasileiro, e de estar a par das mais candentes discussões (como quando referia-se, em artigo de 1927, à palestra pessimista de Worringer, em Londres, sobre a continuidade do expressionismo ${ }^{9}$ ), nada lhe garantia que, ao lançar-se à sua própria produção visual, ele alcançaria algum resultado mais notável. Como se sabe, a posse de um cabedal teórico avançado não garante, per si, uma linguagem de alto nível: fazer linguagem é tentar fazer linguagem. Não há, ao menos dentro da premissa modernista da experimentação constante (que Mário defendeu), garantia alguma dos resultados quando um artista se lança ao processo de criação. Por outro lado, a produção fotográfica de Mário não é ingênua; as questões com que ele dialoga em suas fotos, remetem a uma matriz bastante complexa: há o reconhecimento da realidade brasileira, mas que não se submete ao documentarismo fotográfico estrito senso (capacidade mimética da fotografia, defendida até hoje ${ }^{10}$; ele evita o pictorialismo e não se acomoda ao exotismo fácil, produzindo uma visualidade caleidoscópica, ágil, que subtrai-se à edulcoração do tema enfocado e que afirma a especificidade técnica da fotografia (luz, contra luz, enquadramento inusitado). Enfim, dialoga com a informação fresca que lhe chega, via revistas, da Europa, mas não se deixa apanhar em fórmulas que lhe engessem a expressão de sua subjetividade.

Em que medida o modernismo fotográfico europeu o influencia? Seu acompanhamento das questões estéticas então correntes na Europa pode ser aferido pela presença, em sua biblioteca, de exemplares de L'esprit nouveau e de Der Querschnitt, revistas europeias de vanguarda que apresentam uma ampla amostragem de informação visual então inédita entre nós. Se L'espritnouveau defendia a ascese racionalista e construtivista como modo de engendrar a cultura da época, Querschnitt (que Mário assinou entre 1924 e 1931) colocava-se numa perspectiva modernista bastante abrangente, que poderíamos chamar, provisoriamente e por contraste à revista francesa, de expressionista. Enquanto a revista francesa (editada entre 1920 e 1925) reivindicava o que convencionou-se chamar de "retorno à ordem" (após os excessos do primeiro momento

9 Cf. SCHWARTZ, Jorge. O expressionismo pela crítica de Mário de Andrade, Máriategui e Borges. In: BELLUZZO, Ana Maria (org.). Modernidade: vanguardas artísticas na América Latina. São Paulo: Memorial da América Latina; Editora da Unesp, 1990.

10 Vide KOSSOY, Boris, op. cit. 
modernista, "heroico" e transgressor), a alemã (editada a partir de 1920) trazia, além da produção de extração construtiva (Fernand Léger, em fevereiro de 1925, fotomontagens russas, em junho de 1925), exemplos de arte de caráter francamente "negativo" (textos de Tristan Tzara), assim como tópicos que envolviam uma discussão em torno do primitivo e do espontâneo (artigos sobre jazz e arte africana).

Evidentemente, não se trata de sugerir que a inventividade visual de Mário, no que tange à fotografia, derive apenas e diretamente do que ele pôde ter visto nos sucessivos números da revista berlinense (ou mesmo da francesa): ele fotografava, ocasionalmente, no seio familiar, como quando em visita à fazenda da família em Araraquara. Enquanto artista e pensador, Mário já estava formado quando realiza as "viagens etnográficas": a incorporação de elementos dinâmicos e assimétricos em seu processo criativo está plenamente exemplificada, já então, na sua literatura (pensemos, por exemplo, na criação de Macunaima, que sairia em 1928). A equação será sem dúvida mais complexa, dado que a formação do repertório marioandradino é bastante ampla: mais do que uma "síndrome de influência direta" que fornecesse decalques, modelos de construção visual, trata-se de entender como ele filtrou, em sua sensibilidade polimorfa, o caudal de questões que as vanguardas modernistas propunham: a superação dos modelos pictorialistas que ancoravam a linguagem fotográfica na sintaxe derivada da pintura novecentista; a adoção do experimentalismo como uma prática legítima e constante na busca de novas soluções formais e expressivas; o entrechoque de conteúdos temáticos e compositivos que podiam redundar ora num adensamento simbólico de teor surrealista, ora na fruição de uma espontaneidade que revertia-se na produção de "instantâneos" fotográficos que, ainda que documentassem a realidade vivida, beiravam a abstração. Algumas sequências sugerem mesmo uma fluência perceptiva afim ao cinema, como veremos a seguir nas fotos 235, 236 e $237^{11}$.

O olhar pessoal que Mário desenvolve na sua produção fotográfica oscila perpassa estas possibilidades então candentes: ora usa a fotografia como registro da realidade, ora tende ao experimentalismo, sem ater-se a um regime único. Mário parece estar mais interessado em experimentar com a linguagem fotográfica, em "pintar com a luz", arriscando soluções com o foco e com a fotometria, em composições diagonais, etc. Assim, comparecem tanto os instantâneos, fotos tiradas em função de

11 Números da série "Fotografias", Fundo Mário de Andrade, IEB-USP. Os códigos das fotografias são compostos pela sigla MA-F, seguidos do número com quatro dígitos. 
uma resposta imediata aos assuntos que se impunham, como chapas que apresentam um olhar mais propositivo e articulado.

Der Querschnitt apresenta-nos aquelas que eram as grandes correntes que demarcavam a produção fotográfica alemã da época: uma, ligada à precisão documental e à eficiência técnica que garantia a verossimilhança dos aspectos visíveis da realidade enfocada, era defendida pelo então influente fotógrafo alemão Renger-Patzsch; outra, ligada à renovação experimental dos códigos visuais e à exploração das possibilidades do meio fotográfico, era postulada pelo então professor da Bauhaus, o húngaro László Moholy-Nagy, que levava a fotografia à fotomontagem, à fusão com a pintura e o desenho, bem como à abstração em que intercedia frequentemente o acaso na interação da luz com os materiais fotossensíveis. Der Querschnitt não reproduzia esquematicamente estas duas vertentes; editava-as lado a lado, entremeadas a outros exemplos da produção fotográfica de então.

O olhar de Mário, então definido a favor de uma ampla abertura à informação experimental mas também sempre atento às peculiaridades e especificidades locais, revela-se, nas fotografias feitas nas duas viagens, abalizado com a fervilhante produção internacional. Mário estabelece um jogo ágil entre rigor construtivo e incorporação simbólica, entre apreensão do instante e contemplação.

Consideremos algumas das suas fotos visualmente mais radicais:

Abrolhos parece ter sido feita pela escotilha do navio que o levava ao Norte do país. A área circular deixa-nos ver uma paisagem marinha, discernível enquanto tal, mas o escuro contra campo (o resto do visor retangular da máquina fotográfica) do primeiro plano, sujeito a invasões de luz, causa uma espécie de indeterminação espacial que parece colocar o observador tanto na posição de aferição da realidade externa (a paisagem) quanto de espectador do próprio ato de perceber (a luz que age sobre o próprio globo ocular). (Há a possibilidade de a máquina de Mário ser de fole e ter havido invasão de luz por essa peça, que costumava furar com frequência nas máquinas antigas. Mas não outros indícios desse tipo nas outras fotos.) 


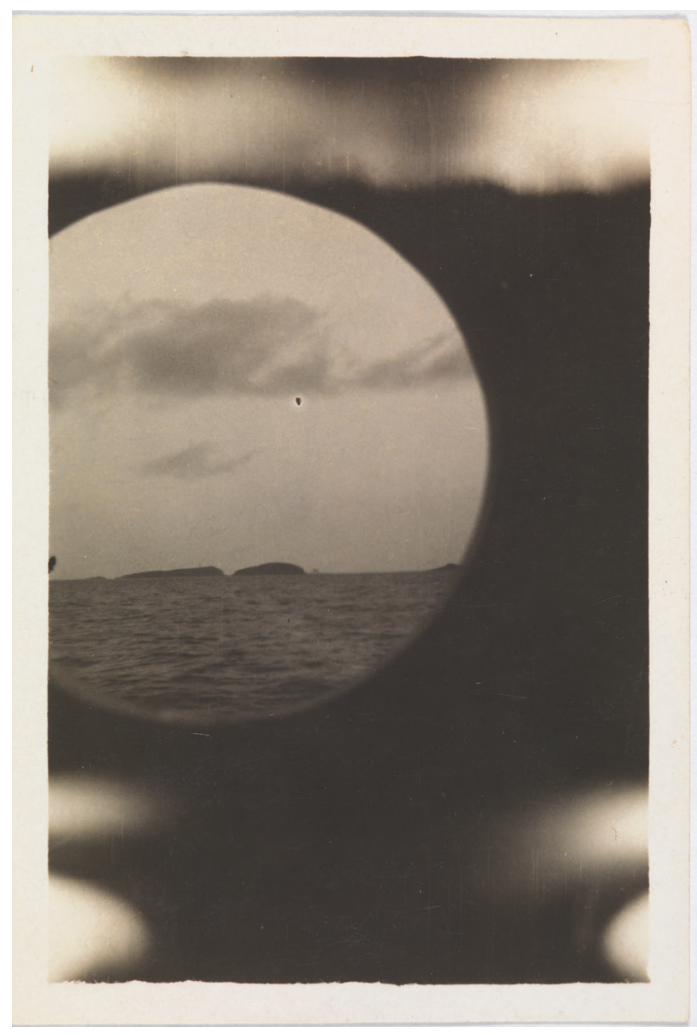

Figura 6: Abrolhos (Código MA-F-0142).

Outra foto que tira partido do acaso é a imagem intitulada, pelo próprio Mário (como todas as legendas, doravante), Futurismo pingando. Dois aspectos sobressaem: trata-se de um instantâneo - um pescador jogando tarrafa; instante documental, com Mário no barco - isto é, dentro da ação. Talvez ele não tivesse percebido naquele momento, concentrado no registro da ação, mas a objetiva foi atingida por alguns pingos d'água. Ao colocar na foto o jocoso nome, a posteriori, ele não só associou a foto à produção artística corrente (chamava-se então de futurismo, em sentido corrente, todo modernismo) como incorporou o que seria um erro ou desvio material (os pingos) à própria linguagem fotográfica. Desse modo, via texto, ele corrige (melhor, incorpora) uma condição tecnicamente falha: a cena é documental e específica, mas a legenda liga-a, em tom de blague, aos "avanços" da linguagem artística. Mário define, assim, toda uma atitude face aos acontecimentos fotográficos com que lida, tanto incorporando as vicissitudes do meio maquínico e seus acasos, quanto 
trazendo-os para uma relação estreita com a legenda textual, isto é, para um conjunto narrativo extremamente pessoal.

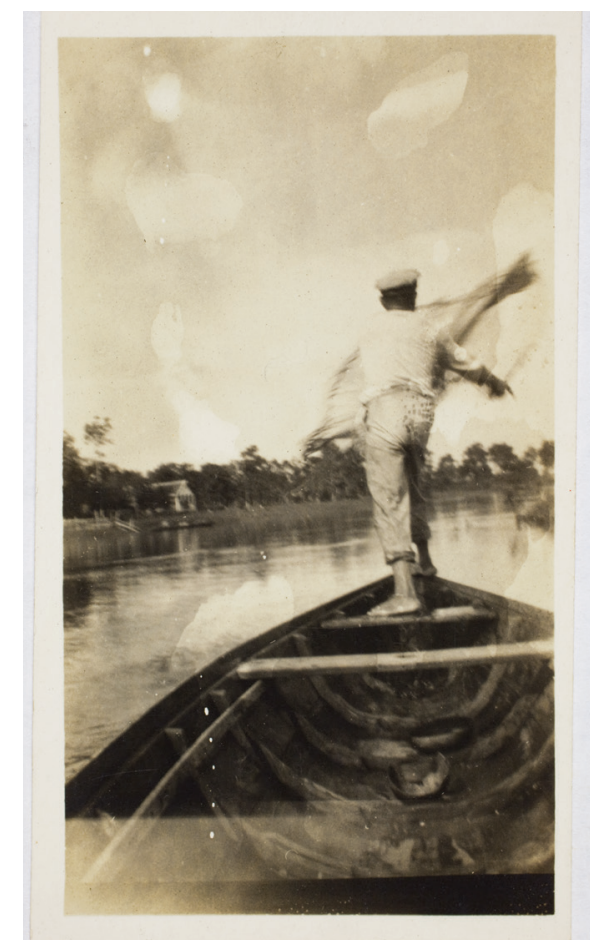

Figura 7: Futurismo pingando (Código MA-F-0235).

Futurismo pingando é a primeira de uma sequência de três imagens que trazem outro dado perceptivo, a cronofotografia, cuja ordem de fotogramas, nos moldes de um Muybridge, é afim ao cinema. São, ao que parece, três arremessos consecutivos de tarrafa, o que implica uma insistência de Mário em relação ao tema (sim, e o que fazer, uma vez que ele está dentro do barco...?) e à busca do "instante decisivo" (para usar a formulação, posterior, de Cartier Bresson), isto é, de um momento significativo e exemplar, que condense em si todo o processo de ações que estão ocorrendo. É significativo que à primeira imagem ele tenha dado o título artístico e humorístico, enquanto no verso das outras duas ele meramente repita a descrição ("Atirando tarrafa igarapé de Barcarena arredores de Manaus 7-VI-27" e "No furo de Bar Carena [Manaus] atirando a tarrafa 7-VI-27 tarrafeando"). De todo modo, há aqui uma série, sequência temporal de quadros que colocam um tema visual e narrativo e suas variações. 


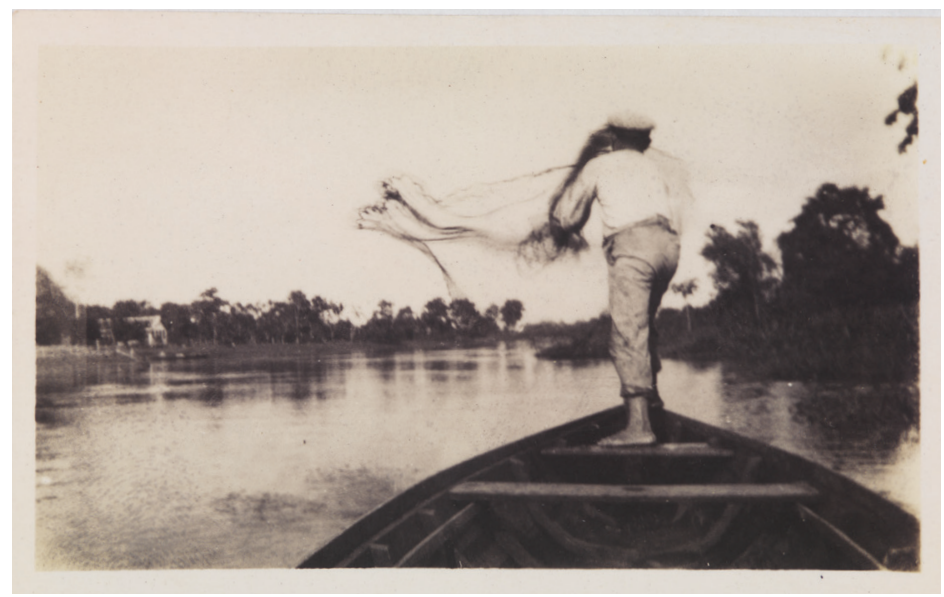

Figura 8: Atirando tarrafa igarapé de Barcarena arredores de Manaus 7-VI-27 (Código MA-F-0236)

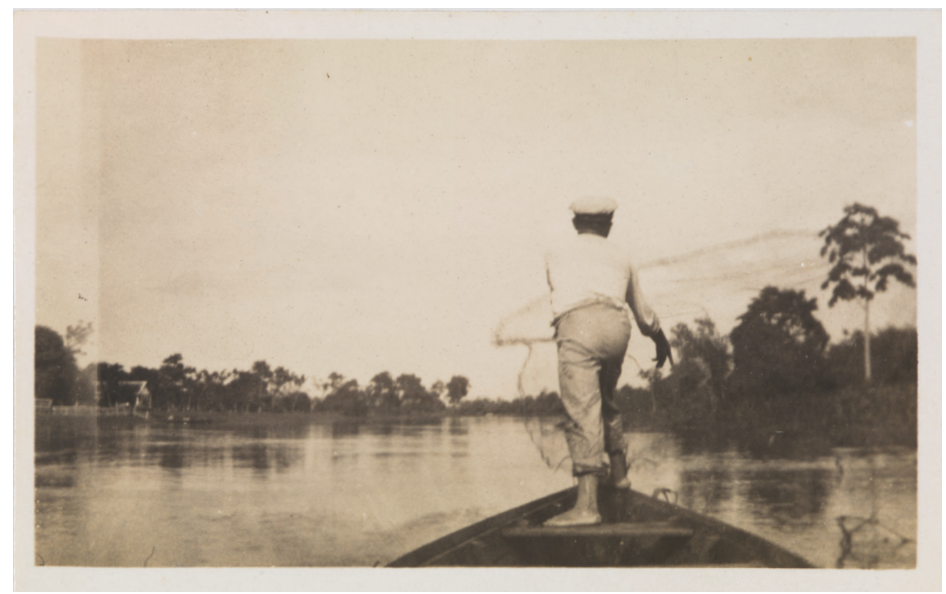

Figura 9: No furo de Bar Carena [Manaus] atirando a tarrafa 7-VI-27 tarrafeando (Código MA-F-0237).

Ainda que sobre a foto da escotilha possa ser alegado que o efeito difuso decorre, talvez, de imperícia técnica ou simples acaso (com o que eu não concordaria), podemos ver que Mário apropria-se das imagens e incorpora-as a um corpus narrativo (por assim dizer) próprio. As duas imagens a seguir fazem parte de sua crônica visual de viagem, mas aludem a campos imaginários bem mais amplos, que extrapolam a narrativa meramente visual: 


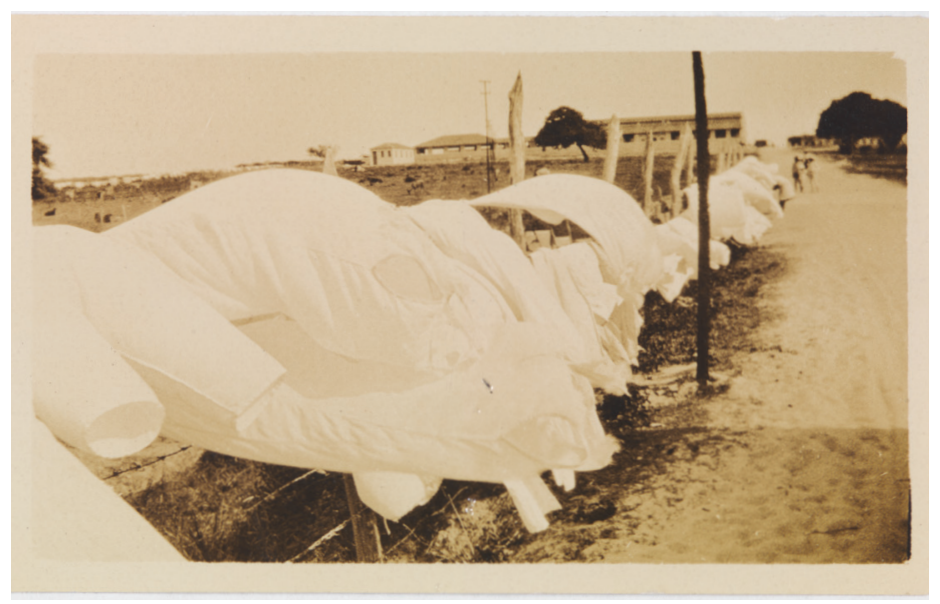

Figura 10: Roupas freudianas Fortaleza 5 VIII 27 Sol 1 diaf 1 Fotografia refoulenta Refoulement (Código MA-F-0589).

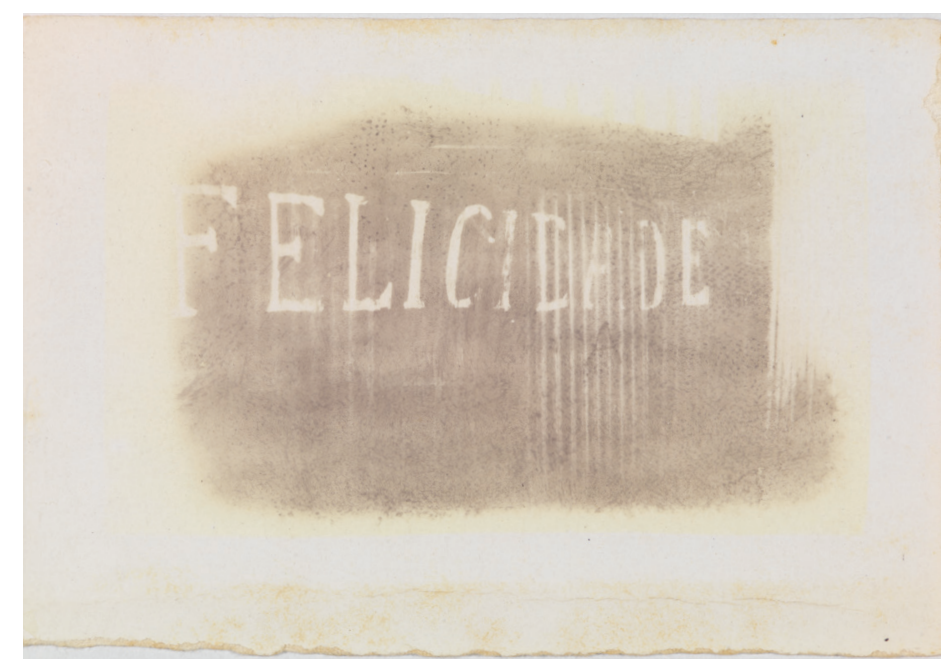

Figura 11: $O$ sítio se chamava FELICIDADE 9-VI-27 Solimões A poesia de Einstein n. 64 (Código MA-F-0259).

A primeira, enquanto construção da linguagem visual, é bastante superior à segunda: uma, apreensão de instante, com enquadramento em diagonal e em profundidade; a outra, simples registro de uma placa. No entanto, Mário associa ambas, com suas legendas, a contextos psicológicos abrangentes: o inconsciente e a estabilidade emocional (a que ele apõe curiosamente, no verso, o comentário: "a poesia de Einstein"). Sem dúvida, podemos associar essas imagens à poética surrealista. Devemos 
também notar o registro, no verso da primeira foto, do diafragma usado e da condição de luz atuante para a foto: denota seu esforço para aferir condições de controle da técnica fotográfica.

Se essas imagens pertencem ao campo das associações inconscientes e da ativação simbólica de cunho psicológico, temos, num registro de linguagem bastante diverso, algumas fotos nas quais Mário opera um léxico decididamente construtivo, em que a geometrização dos elementos no campo visual define a aproximação aos temas:

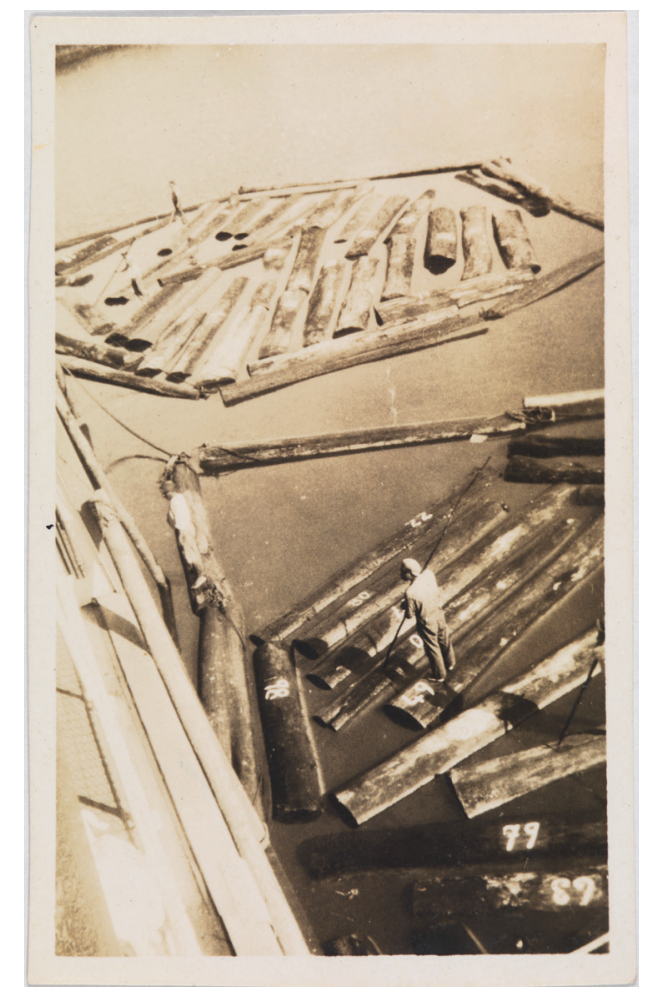

Figura 12: Jangadas de mogno encostando no S. Salvador pra embarcar Nanay 23 de junho Peru Vitrolas futuras (Código MA-F-0320).

Jangadas de mogno encostando no S. Salvador pra embarcar Nanay 23 de junho Peru Vitrolas futuras nos mostra toras de mogno flutuando ao lado do barco. A composição tem linhas de força em diagonal, com a curiosa configuração superior poliédrica. A imagem informanos sobre o transporte da madeira por via fluvial, mas sua composição severa atesta que o autor está mais interessado, naquele instante, no jogo de linhas e geometrias ínsitas à ação, que em preservar a estabilidade 
das linhas de força naturais (a linha de horizonte que pode-se adivinhar ao fundo e acima da imagem, no canto superior esquerdo).

A mesma disposição ocorre em Almoço da 3 a classe Baependy - ao largo 6 VIII 27 diaf 1 sol 1 das 10 Em terceira voracidade. Sem dúvida, era um enquadramento confortável ao autor, que estava no convés superior do barco mas, com um pequeno esforço de imaginação, podemos supor que havia inúmeras outras possibilidades de posicionamento da máquina (e de seu corpo). Por que então esta reincidência, como em Rua Nova Recife II-29 da minha janela de hotel, em que Mário estava, não num barco, mas na janela de um hotel? Sem dúvida, ele estava interessado em investigar essa possibilidade de enquadramento, ousado e radical, para os padrões de linguagem da época.
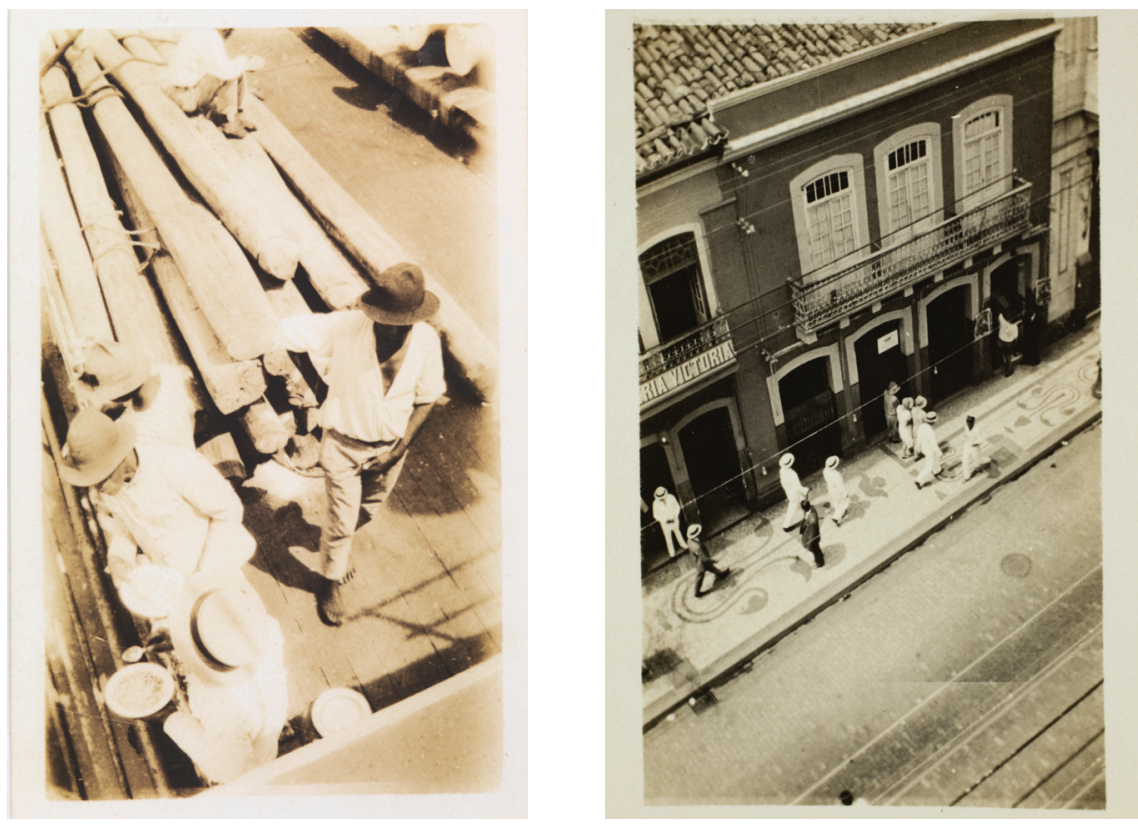

Figura 13: (Esq.) Jangadas de mogno encostando no S. Salvador pra embarcar Nanay 23 de junho Peru Vitrolas futuras (Código MA-F-0320).

Figura 14: (Dir.) Rua Nova Recife II-29 da minha janela de hotel (Código MA-F-1142).

O enquadramento extremo, de um ponto de vista espacialmente superior ou inferior, recusando a vista frontal (usual, documental, referente ao plano do chão como plano de estabilidade para a construção e leitura da imagem) estava sendo bastante explorado então, como novidade destinada a intensificar e a potencializar os elementos construtivos 
da imagem. Rodchenko, fotógrafo russo frequentemente reproduzido em Der Querschnitt, explorou decididamente essa opção compositiva, e Mário estava a par desta condição, como mostra a sua coleção desta revista. Não quero sugerir que ele copiasse ou se pautasse diretamente no russo (ou em outro fotógrafo), mas o uso reiterado dessa disposição gráfica constitui-se, à época, uma estratégia nova, fresca, uma nova perspectiva possível de registro e de reelaboração formal da linguagem visual.

Muito diverso, mas tão engenhoso, e mais sutil, é o expediente usado para registro das grandes amplidões amazônicas. Mário, no texto d'O turista aprendiz, sublinha frequentemente a inapreensibilidade do espaço amazônico, cujas dimensões desafiam os sentidos e a linguagem. Em algumas das fotos, em vez de concentrar-se nas linhas de força como nas imagens de corte diagonal (em que ele parece esconder ou descartar a linha do horizonte), Mário apoia a construção da imagem justamente na linha do horizonte, a que contrapõe, no ato do enquadramento, alguns elementos.

A imagem Entrada dum Paraná ou Paraná 5-VII-27 rio MadeiraIlha de Manicoré O I é o Madeira o II é o furo de Manicoré rio Mataurá Entre duas águas nos dá uma panorâmica praticamente sem recurso de escala, salvo uma haste, provavelmente da cobertura da barca. Para tornar a grandeza da paisagem legível, Mário insere escalas humanas nas imagens subsequentes.

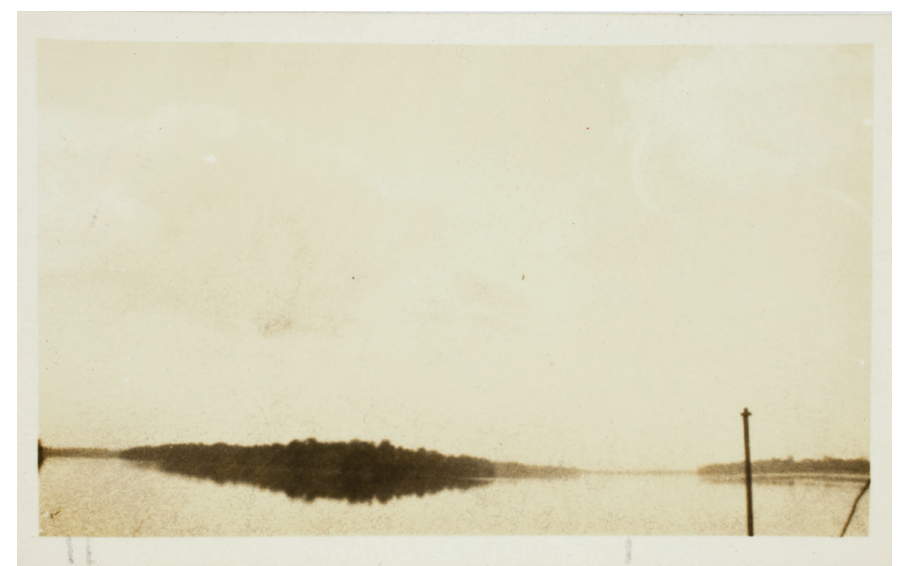

Figura 15: Entrada dum Paraná ou Paraná 5-VII-27 rio Madeira - Ilha de Manicoré O I é o Madeira o II é o furo de Manicoré rio Mataurá Entre duas águas (Código MA-F-0368). 
É o caso das imagens $O$ gaiola Índio do Brasil vindo atracar no vitória em Pariri, Madeira 17-VII-27 Retrato do barbeiro de bordo Sol 2 Diaf. 1 Manhã e Barbeiro, Dolur na vista Mara Joara 31 VII 27 Sol 3 diaf. 3 Trombeta e $O$ Vitória no Madeira se vê o 10 plano margem esquerda do igarapé de Três Casas Foto tirada barranca alta, direita do mesmo igarapé 7-VII-27.

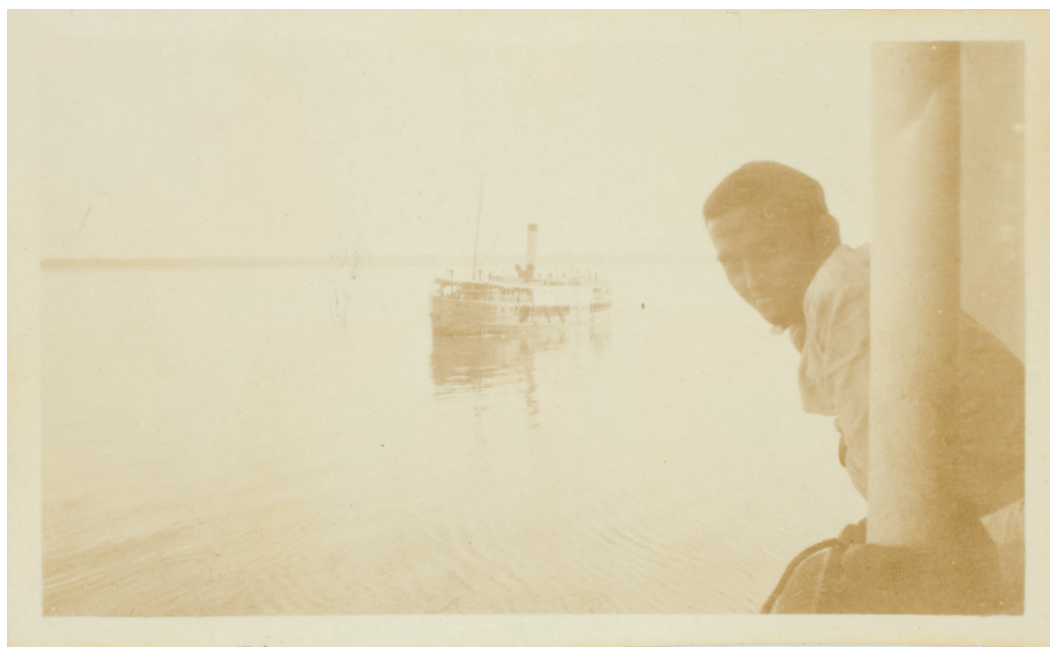

Figura 16: O gaiola Índio do Brasil vindo atracar no vitória em Pariri, Madeira 17-VII-27 Retrato do barbeiro de bordo Sol 2 Diaf. 1 Manhã e Barbeiro (Código MA-F-0453).

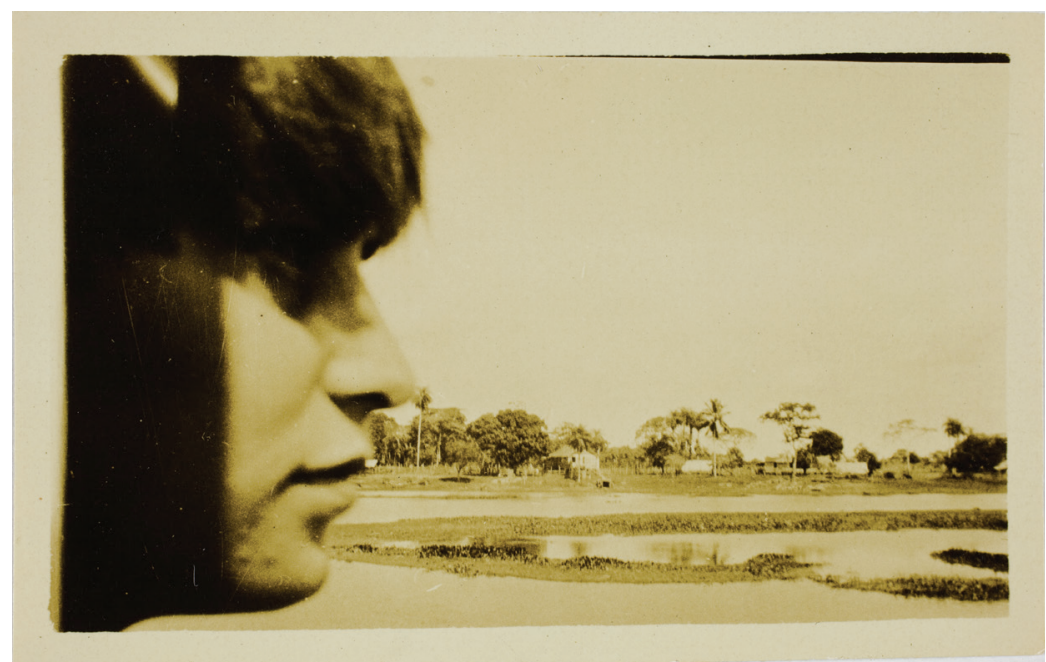

Figura 17: Dolur na vista Mara Joara 31 VII 27 Sol 3 diaf. 3 Trombeta(Código MA-F-0568). 
Nas duas primeiras imagens, temos a linha do horizonte ocupando quase toda a extensão longitudinal do campo visual. No entanto, Mário cuidadosamente enquadra uma pessoa (o barbeiro de bordo, na primeira, e Dolur, companheira de viagem, na segunda imagem) num dos extremos do campo visual (à direita ou à esquerda). Assim, temos que à imensidão da paisagem, contrapõe-se um elemento que ajuda a dar dimensão apreensível ao espaço de fundo. Ao distante, contrapõe o próximo; à geometria da linha horizontal, faz corresponder o corpo humano, ou primeiro plano cortante, como na imagem da barca no rio Madeira. Desse modo, Mário faz uso do expediente que, desde o fim do século XVIII, era comumente usado em pintura quando se queria registrar grandes panoramas: insere uma figura humana que funciona como escala, a partir da qual pode-se estimar as grandezas visualmente envolvidas no jogo da paisagem. Assim, ele recorre a um cânone da estética do sublime, em que o contraste entre o muito grande e muito pequeno (a escala humana) concorrem para o efeito geral que se pretende: expressar a imensidão da natureza. Essas imagens não devem ser confundidas com os retratos enquanto tais: o corpo (ou rosto) humano aparece aqui como elemento da retórica da imagem. Para os retratos, vejamos a seguir.

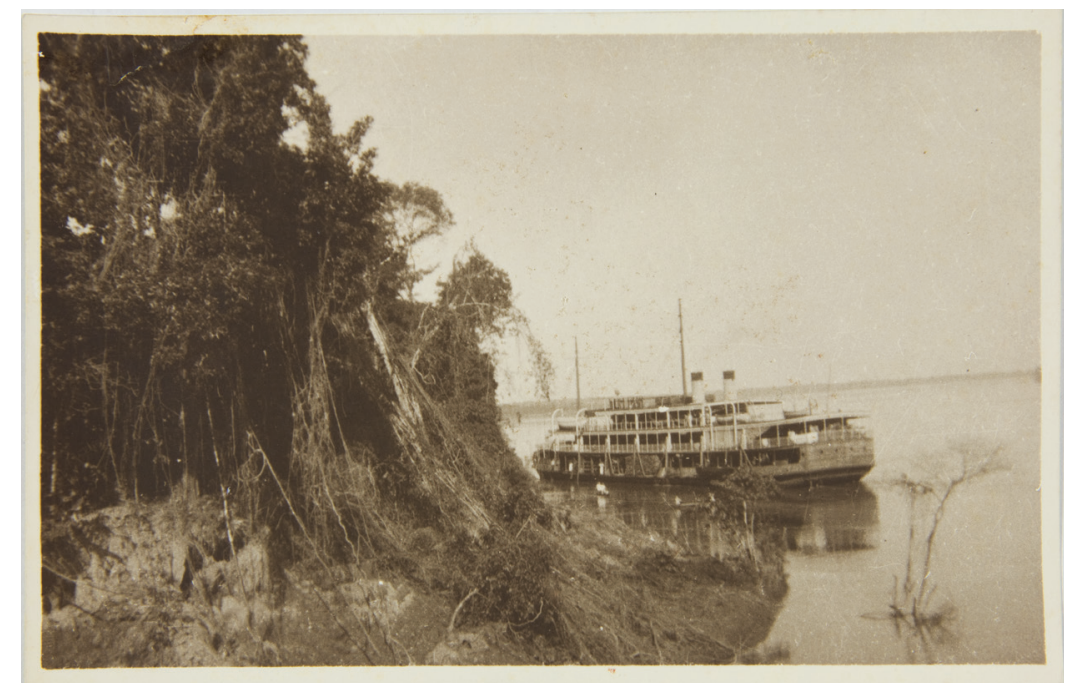

Figura 18: O Vitória no Madeira se vê o 10 plano margem esquerda do igarapé de Três Casas Foto tirada barranca alta, direita do mesmo igarapé 7-VII-27 (Código MA-F-0386). 
O retrato que Mário intitula Na lagoa do Amanium perto (?) do Igarapé de Barcarena Manaus 7-VI-27 Minha obra prima condensa tanto um retrato quanto a visão da paisagem circundante, vista em plano médio. Talvez por isso - pelo olhar direto do retratado, pela clareza descritiva da paisagem, pela circunstância da foto (autor dentro do barco, como na série das tarrafas), bem como por detalhes peculiares, como a flor entre a vitória régia e o barco - Mário considere essa imagem sua "obra-prima". A figura humana, diferentemente da série anterior, dos "panoramas", ganha força compositiva, definindo diagonal abrupta em primeiro plano. Trata-se de um retrato que tem todas as características clássicas de representação visual, em que a relação entre temas expostos e composição redunda numa imagem "fechada", da qual nada se tira, nada se põe e à qual nada falta.

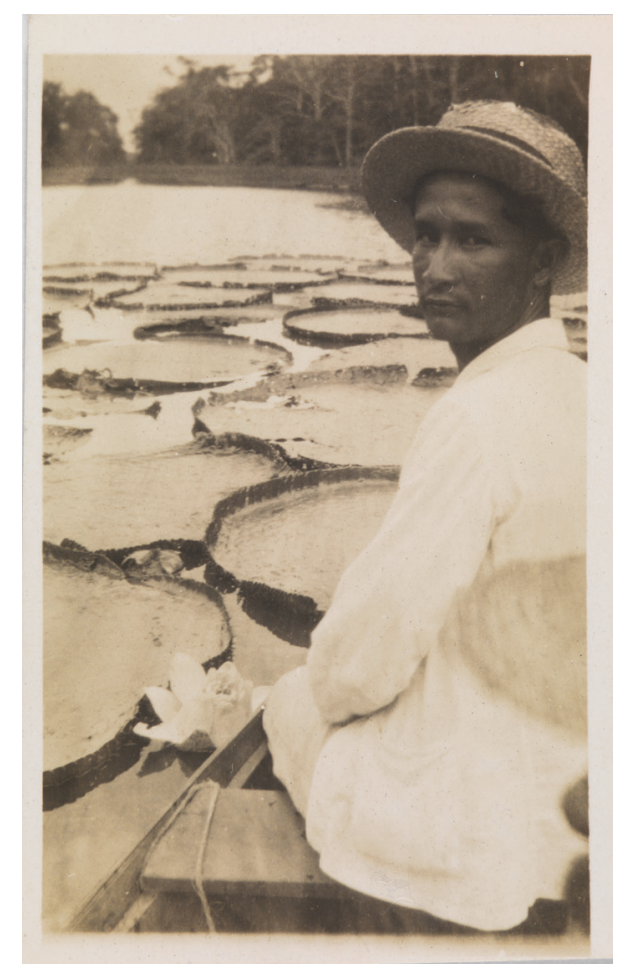

Figura 19: Na lagoa do Amanium perto (?) do Igarapé de Barcarena Manaus 7-VI-27 Minha obra prima (Código MA-F-0250).

Muito diferente é Assacaio 17-VI-27 O mais alto esse e negre enegrecido pintado de genipapo, que tem um caráter menos formal, pode-se dizer, em virtude da atividade e da ação paralela que parece estar envolvida na 
cena. Se a cena define-se frontalmente em função do par central - principalmente o homem de expressão carregada (pressupõe-se que seja um carregador ou estivador, devido ao capote de proteção que ele e o rapaz ao fundo usam) -, os elementos do fundo deixam a cena "em aberto" - barco, céu, homens ao fundo, sugerindo continuidade espacial e de ação.

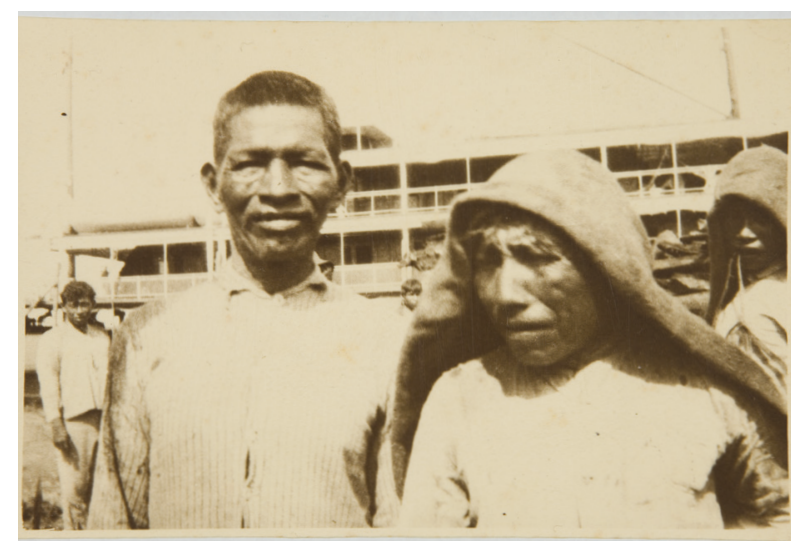

Figura 20: Assacaio 17-VI-27 O mais alto esse e negre enegrecido pintado de genipapo (Código MA-F-0283).

Nem tão perfeita em termos compositivos quanto a primeiro retrato, nem tão inquisitivo quanto o segundo, é Crilas de Assacaio 17-VI-27 Alto Solimões “...o homem que tirou fotografia da gente...", de um grupo de crianças ribeirinhas. O registro documental, descritivo, sem dúvida comanda a fotografia, dadas as feições das crianças (índias? Cafusas?).

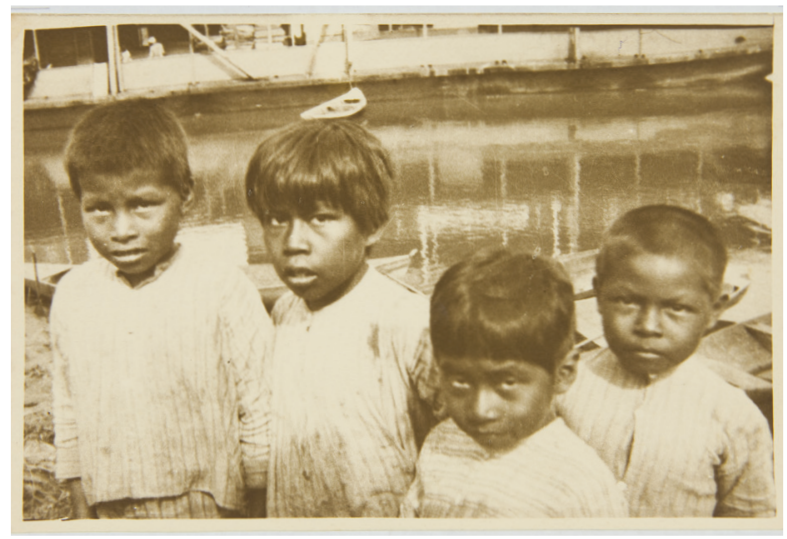

Figura 21: Crilas de Assacaio 17-VI-27 Alto Solimões “...o homem que tirou fotografia da gente..." (Código MA-F-0290). 
O mesmo poderíamos dizer de Boniteza tapuia: de fato ela era mais bonita que o retrato S. Salvador VIII 27 A Venus de milho, não fosse pela consonância entre a ligeira superexposição luminosa e o brilho nos olhos da moça, cuja expressão entre melancólica ou reticente confere um caráter mais psicológico à foto. Talvez houvesse algum leve desconforto no encontro (ele teria pedido permissão? Ela desviou o olhar levemente?), superado pela densidade poética que o retrato, afinal, alcançou. Além disso, o posicionamento em $3 / 4$ (e não frontal, como os dois anteriores) reforça a referência ao cânone artístico, em que as angulações frente ao modelo tem papel retórico importante.

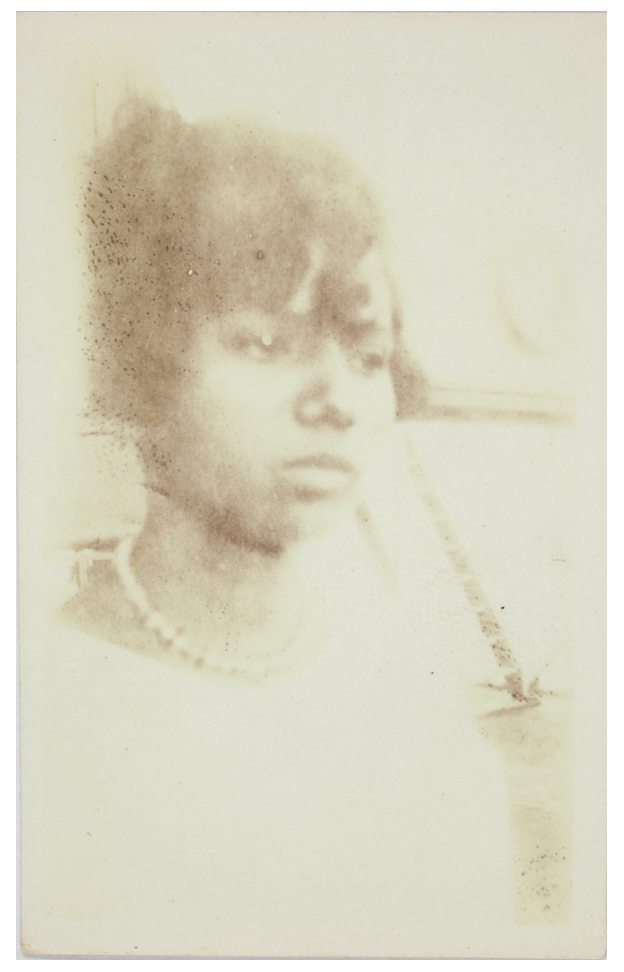

Figura 22: Boniteza tapuia: de fato ela era mais bonita que o retrato S. Salvador VIII $27 \mathrm{~A}$ Venus de milho (Código MA-F-0355).

Um retrato de grupo, Procissão de Maria 31 de maio de 1927 Santarem Santa que vai santa que vem Tem procissão em Santarem, recoloca a questão do enquadramento e do acaso: Mário está praticamente dentro do grupo. Ele corta verticalmente a cena com a moça à esquerda, com o grupo desdobrando-se para a direita e ao fundo, até o 
estandarte da procissão. No entanto, um acaso feliz fez com que a criança central, perfeitamente focada e iluminada, voltasse o rosto para o autor. Este acaso (terá Mário chamado a criança, naquele instante?) criou a força maior da imagem: a cumplicidade entre observador e observado.

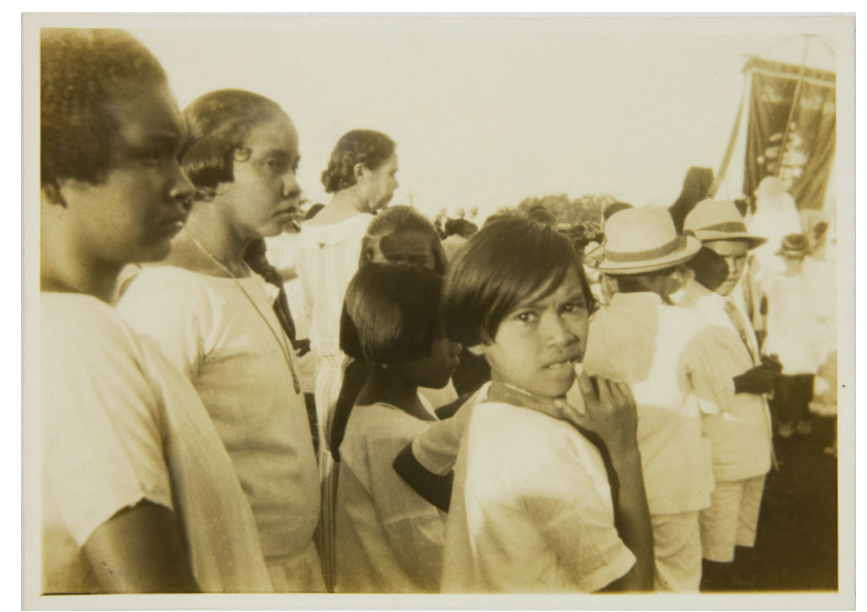

Figura 23: Procissão de Maria 31 de maio de 1927 Santarem Santa que vai santa que vem Tem procissão em Santarem (Código MA-F-0211).

O fato é que, tanto num registro mais clássico e controlado quanto em instantâneo ocasional, Mário alcança um registro de linguagem visual bastante vigoroso e consciente, com variadas estratégias de aproximação aos seus temas.

Não é à toa que ele tinha em sua coleção original um cartão postal, assinalado no verso Parintintin / Cararnerê, que informa, de modo quase científico (visões de frente e perfil, contra fundo neutro, eliminadas variáveis e interferências à observação objetiva), as características fisionômicas de um índio. Essa seria uma foto que poderia muito bem ter sido tirada por um Marc Ferrez, bem como por um Paul Ehrenreich (antropólogo e fotógrafo que acompanhou Karl von den Steinen em uma de suas viagens ao Brasil central trinta anos antes das viagens de Mário). Mário conhecia essas contribuições e - o cartão assim o mostra - os modos de representação antropológicas em uso. Aproximar-se ou distanciar-se destes cânones era uma questão de preferência e de ocasião ou, para usar um termo mais impressionista, de "espanto", isto é, de reação à própria condição dos encontros (distância, atitude corporal e acordo psicológico entre autor e objetos, incidência e qualidade da luz etc.). 


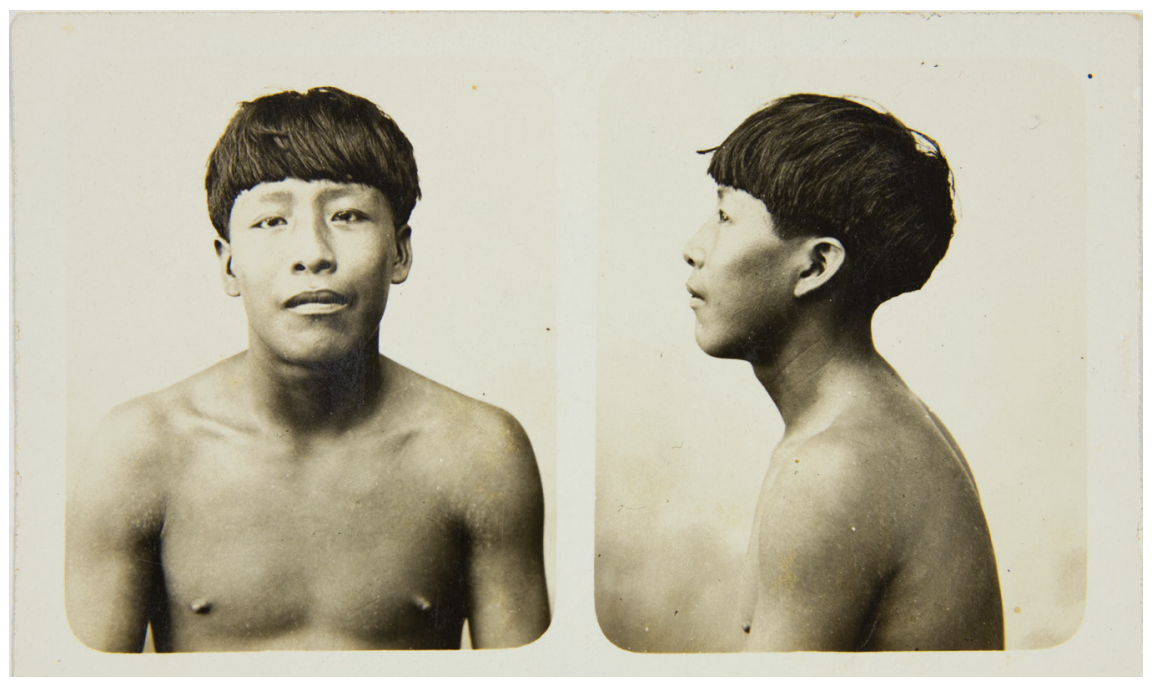

Figura 24: Parintintin / Cararnerê (Código MA-F-0671).

Não há timidez nas fotos de Mário: ele enfrenta as situações, reagindo de modo variado a eles, seja frente a pessoas, à paisagem ou a assuntos que são eminentemente gráficos, como situações de luz extrema, desafio comum aos fotógrafos.

Isso fica evidente em fotos como Piás se banhando num igarapé Iquitos 24-VI-27, em que o assunto é menos as fisionomias das crianças do que a situação geral, menos a geometria dos elementos dispostos no campo visual que a invasão de contraluz. A foto é uma reação ao momento. Decorre daí que a foto registra tanto um conjunto de sensações (a luz, a água, a imersão e o aceno de um dos piás), uma resposta em bloco à situação, quanto inventaria um modo de vida ribeirinha. Na manipulação da condição de luz, a imagem aparenta-se a Abrolhos, primeira da série aqui analisada. 


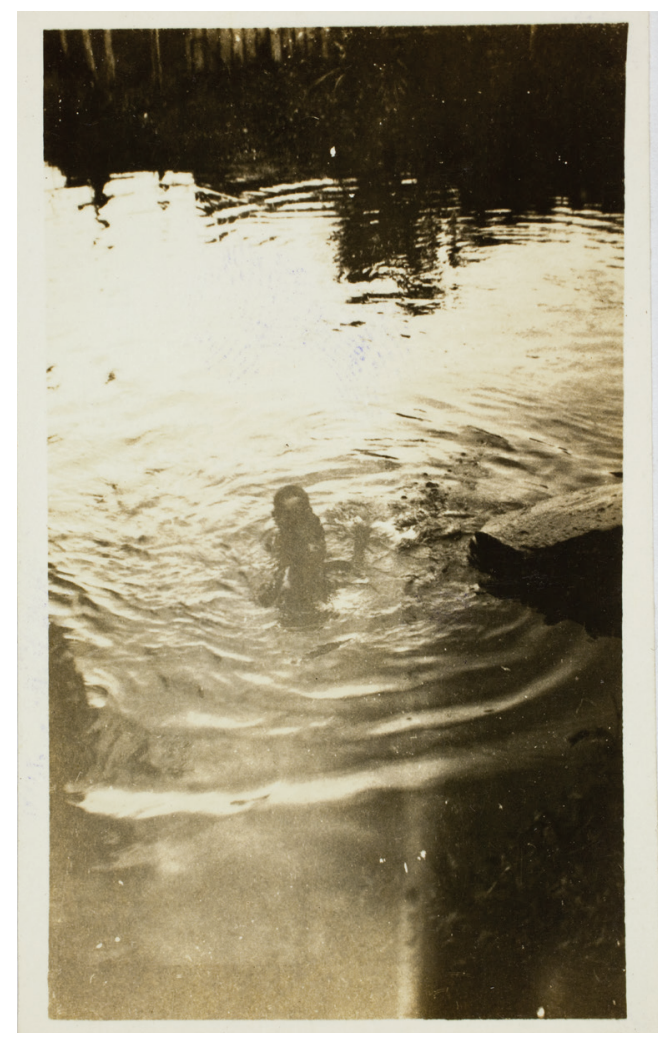

Figura 25: Piás se banhando num igarapé Iquitos 24-VI-27 (Código MA-F-0329).

A mesma relação com a luz (e com a sombra), acha-se em duas outras fotos: Rio Madeira Retrato de minha sombra trepada no toldo do Vitória julho 1927 Que dê o poeta? e na foto mais famosa desse tipo Sombra minha/ Sta. Teresa do Alto I-I-28, que é capa do Mário de Andrade: fotógrafo e turista aprendiz. Em ambas Mário fotografou a própria sombra, primeiro sobre o teto da barca, e na segunda sobre o chão de terra.

Na primeira, temos a contraposição entre sua sombra, minúscula na base do enquadramento vertical, e a água, acima da qual ergue-se a vegetação da margem oposta do rio. Aqui Mário brinca com as inversões e contraposições (água-céu, muito pequeno versus muito grande, objeto-sombra) e traz de novo o jogo de equivalências (contrastes) entre paisagem e corpo humano. Ele transforma o jogo de sombras num esconde-esconde ("que dê o poeta?"), desdobrando referências e identidades. Desse modo, ele questiona a própria especificidade da fotografia, como fenômeno luminoso e fato ontológico. 

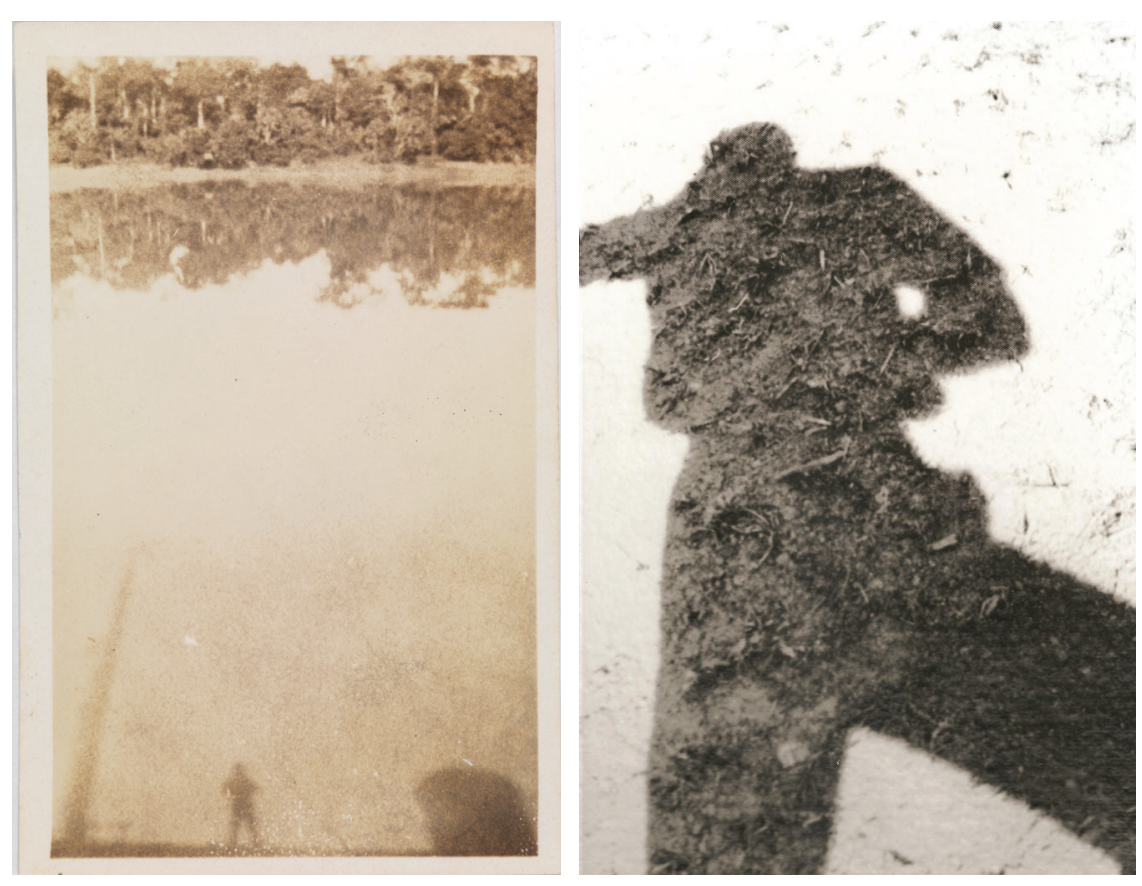

Figura 26:(Esq.) Rio Madeira Retrato de minha sombra trepada no toldo do Vitória julho 1927 Que dê o poeta? (n. 417 da Coleção Mário de Andrade do IEB-USP).

Figura 27: (Dir.) Sombra minha/ Sta. Teresa do Alto I-I-28 (n. 752 da Coleção Mário de Andrade do IEB-USP).

Retornando às possibilidades mais prosaicas da fotografia, temos também as fotos de documentação paisagística, urbana e arquitetônica. Praia de Boa viagem Recife Boa Viagem no Recife bem como Olinda Igreja de São Bento II-29 tiram partido da dimensão dos coqueiros para enquadrar as construções. Desse modo, a arquitetura aparece inscrita na paisagem natural, sempre em $3 / 4$, isto é, em ângulo que inclui a espacialidade circundante e que valoriza o diálogo entre artefato humano e natureza. Ligeiramente diferente é Veneza em Santarém junho 1927 É o hotel 31 de Maio To be or not to be Veneza Eis aqui estão ogivas de Santarém, que tende ao registro frontal, uma vez que a peculiaridade aqui é o fato da arquitetura ter janelas ogivais, típicas do gótico veneziano. 


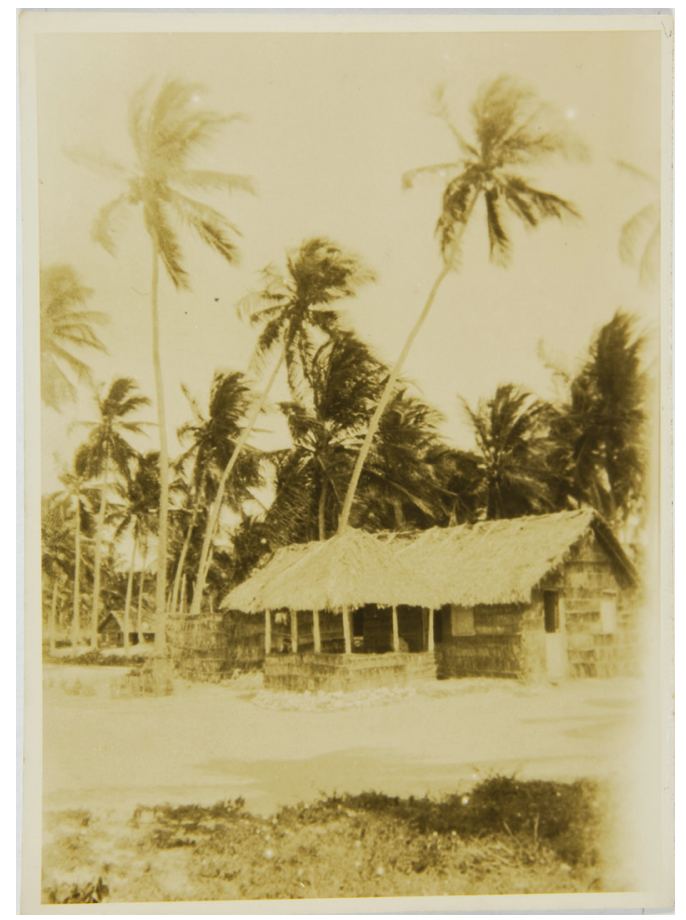

Figura 28: Praia de Boa viagem Recife Boa Viagem no Recife (Código MA-F-0154).

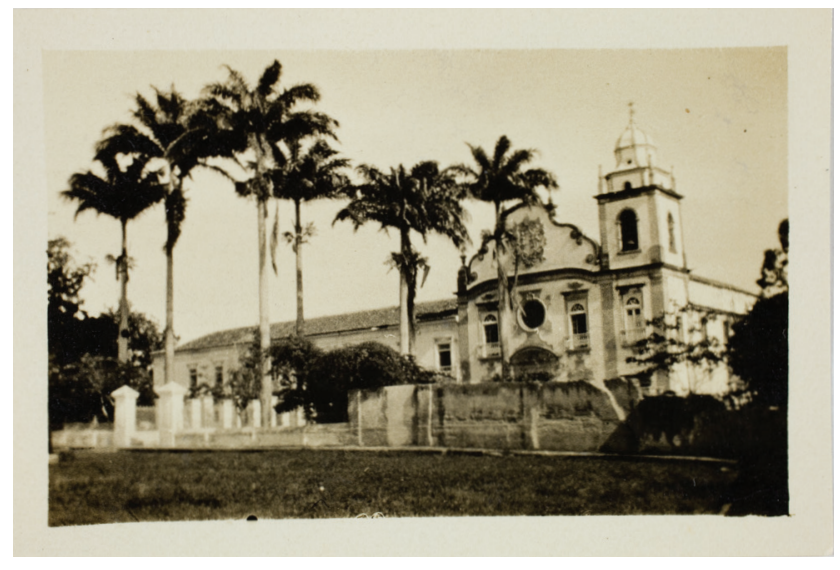

Figura 29: Olinda Igreja de São Bento II-29 (Código MA-F-1154). 


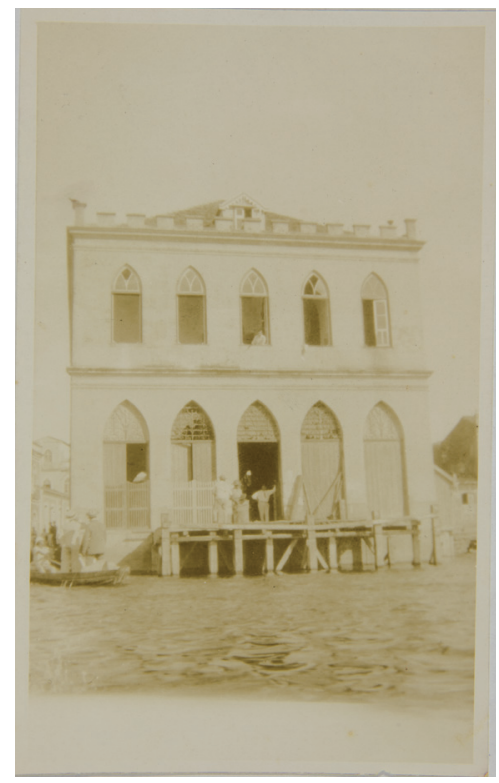

Figura 30: Veneza em Santarém junho 1927 É o hotel 31 de Maio To be or not to be Veneza Eis aqui estão ogivas de Santarém (Código MA-F-0206).

De todo modo, essas três imagens são registros fidedignos da arquitetura e dos espaços que Mário tem diante de si. A já mencionada Rua Nova Recife II-29 da minha janela de hotel, que apresenta enquadramento em fraca diagonal profunda, nos traz, enquanto documentação urbana, o espaço da rua, construções, calçadas adornadas, tipos humanos, informando sobre o teor de urbanidade daquela capital. Arrojo compositivo e caráter descritivo são qualidades inerentes à imagem.

As fotos de Mário são emblemáticas de uma nova compreensão das possibilidades da linguagem fotográfica entre nós, fenômeno que ocorre com certo atraso em relação às outras artes visuais (pintura, escultura e arquitetura) modernistas brasileiras. Na realidade, seriam precisos alguns bons anos para que estes expedientes criativos se tornassem correntes mesmo entre fotógrafos profissionais (apenas no pós-guerra e, decididamente, na década de 1950, a abstração faria parte das estratégias de linguagem visual). Ele compreendeu de imediato, ao ser apresentado a essas novas linguagens, suas potencialidades, e exerceu-as. Neste pequeno grupo de fotografias que analisamos, procuramos evidenciar algumas diferentes estratégias de construção de suas imagens. 
Essa mobilidade de recursos expressivos presentes permite a Mário transitar entre "universos de visualidade", indo de um registro documental para um outro mais subjetivo, e assim por diante. Ele experimenta com a linguagem fotográfica sem trauma ou esforço, explorando em rápida sucessão as possibilidades de representação que surgiam com as vanguardas modernistas - documentação, experimentação, construtivismo, simbolismo, abstração. Por outro lado, ele soube tirar partido da relação de imediaticidade e mobilidade corporal proporcionada então pelos avanços técnicos da máquina Kodak - pequena, mais leve que as máquinas anteriores. Sua produção, apesar de numericamente pequena, apresenta uma densidade qualitativa e um caudal de questões de linguagem que só seriam plenamente desenvolvidas anos mais tarde, em contextos mais formais de produção (jornalismo, fotoclubismo, círculos artísticos). Deste modo, mesmo num meio expressivo em que atuou como "amador", e em contato com realidades que lhe eram presencialmente novas, ele colocou em prática sua premissa de permanente pesquisa estética.

\section{Sobre o autor:}

\section{Douglas Canjani}

Professor Doutor Assistente da Pontifícia Universidade Católica de São Paulo. Possui graduação, mestrado e doutorado em Arquitetura e Urbanismo pela Universidade de São Paulo.

E-mail: canjani@pucsp.br 
